\title{
Pay it forward: refuse dump from leaf-cutting ants promotes caterpillar digestive performance by increasing plant nitrogen content
}

\author{
MARIA NATALIA LESCA N O, ${ }^{1}$ C C A R O L I A Q U I N T R O ${ }^{1}{ }^{1}$ \\ A L E J A N D R O G US TAV O FA R J I - B R E N E R ${ }^{1}$ (D) \\ and E S T E B A N B A L S E I R O ${ }^{2}$ (i) ${ }^{1}$ Laboratorio Ecotono INIBIOMA, CRUB, CONICET, Universidad \\ Nacional del Comahue, San Carlos de Bariloche, Argentina and ${ }^{2}$ Laboratorio de Limnología, INIBIOMA, CRUB, CONICET, \\ Universidad Nacional del Comahue, San Carlos de Bariloche, Argentina
}

\begin{abstract}
The activity of soil-disturbing animals that increase soil nutrients can affect the carbon : nitrogen $(\mathrm{C}: \mathrm{N})$ ratio of plants, which, in turn, may determine the transfer of energy and nutrients through higher trophic levels. However, the strength and sign of this indirect effect depend on whether enhanced nutrient substrates increase plant foliar nutrients and/or plant defensive traits.

2. We investigated how the nutrient-rich refuse dumps of the leaf-cutting ant Acromyrmex lobicornis, as a result of their direct effects on thistles, indirectly impact the growth rate and digestive performance of a generalist chewing herbivore. We also included the application of commercial fertilisers to test whether the enhanced soil nutrients comprises the mechanism behind the impact of refuse dumps on the upward cascade effects.

3. Thistles growing on nutrient-rich substrates (i.e. ant refuse dumps and fertilised soil) had more and larger leaves, up to $80 \%$ lower $\mathrm{C}: \mathrm{N}$ ratios, and higher physical defences compared to plants growing on steppe soil. Caterpillars showed an enhanced digestive performance and growth rate when feed on nutrient-rich plants and were able to adjust the $\mathrm{C}: \mathrm{N}$ ratio of their excretion to regulate the relative acquisition of nutrients.

4. The positive effect of nutrient-rich substrates on caterpillar feeding efficiency suggest that the enhanced nutritional quality of the thistles could compensate for the negative effects of the increased physical defences. The results of the present study indicate how organisms that increase soil nutrient availability may diminish the stoichiometric constraints at the base of food chains, enhancing the development and growth rate of herbivores and, thus, indirectly mediating plant-herbivore interactions.
\end{abstract}

Key words. Acromyrmex lobicornis, Copitarsia gibberosa, ecological stoichiometry, nutritional indices, soil nutrients.

\section{Introduction}

Soil nutrient enrichment can alter several plant tissue quality traits, which, in turn, can affect the nutritional value of the plant for herbivores (Kerslake et al., 1998; Stiling \& Moon, 2005; Hunter, 2016). The reduction in the carbon : nitrogen $(\mathrm{C}: \mathrm{N})$

Correspondence: María N. Lescano, Laboratorio Ecotono INIBIOMA, CRUB, CONICET, Universidad Nacional del Comahue, Quintral 1250, 8400 San Carlos de Bariloche, Río Negro, Argentina. E-mail: nataliales@gmail.com ratio of plants generated by soil nutrient enrichment is expected to indirectly enhance the survival, growth, and reproductive rates of herbivores (Perkinns et al., 2004; Stiling \& Moon, 2005; Huberty \& Denno, 2006). However, a more nutritious soil substrate may also improve plant anti-herbivore defence, reducing tissue palatability for herbivores (Bryant et al., 1983; Cipollini \& Bergelson, 2001; Dyer et al., 2004). Therefore, the indirect effect of enhanced soil nutrients on the performance of herbivores may vary from positive to negative across herbivore species and ecosystems. 
In arid and semi-arid regions, soil nutrients are important limiting factors for plant growth (Noy-Meir, 1973; Hartley et al., 2007); therefore, the activity of organisms promoting nutrient-rich patches is of particular relevance (Mun \& Whitford, 1990; Eldridge \& James, 2009; Farji-Brener \& Werenkraut, 2017). By generating physical and chemical changes in the environment that they inhabit, leaf-cutting ants are one of the most prominent soil-disturbing animals known to positively affect plant fitness (Farji-Brener \& Werenkraut, 2015). In addition, the soil nutrient hot-spots created by these ants (hereafter refuse dumps) can also affect plant physical and/or chemical defence traits, changing plant susceptibility to herbivores (Farji-Brener, 2007). Yet, how plants allocate the excess of resources generated by soil-disturbing animals among growth, reproduction, and defence is not easy to predict because empirical evidence has questioned the paradigm of a classical trade-off between these functions (Koricheva, 2002; Agrawal, 2011; Neilson et al., 2013) and supported scenarios where trade-offs, if present, might be transient or context-dependent (Orians et al., 2010; Sampedro et al., 2011; Hoque \& Avila-Sakar, 2014).

Field studies conducted in the Patagonian steppe showed that plants around nests of the leaf-cutting ant Acromyrmex lobicornis have access to the nutrients of refuse dumps, growing better and producing more seeds than plants far from ant nests (Farji-Brener \& Ghermandi, 2008; Lescano et al., 2012). Among the most common colonisers of A. lobicornis nest areas is the thistle Carduus thoermeri (Farji-Brener \& Ghermandi, 2008), an exotic herb very abundant in disturbed areas that also benefits from growing on ant refuse dumps (Farji-Brener \& Ghermandi, 2008; Farji-Brener et al., 2009). However, how these changes in plants growing on refuse dumps might affect the performance of herbivores that feed on this plant species remains poorly explored. Given that $C$. thoermeri plants play a key role supporting aphid and aphid-tending ant assemblages (Farji-Brener et al., 2009; Lescano \& Farji-Brener, 2011) and are often damaged by caterpillars (M. N. Lescano and C. Quintero, personal observations), understanding how herbivores of this plant species are indirectly affected by the nutrient-rich refuse dumps of A. lobicornis becomes critical for predicting the potential invasion success of this exotic species and its role on this ecosystem.

We experimentally examined how the enhanced nutrients available in the A. lobicornis refuse dumps, as a result of their direct effects on thistles, impact the growth rate and digestive performance of Copitarsia gibberosa Pogue (Lepidoptera: Noctuidae), a generalist chewing herbivore of economic importance (Gould et al., 2005; Pogue, 2014). We performed a common garden experiment aiming to test whether a nutrient-rich substrate (ant refuse dumps) impacted growth, nutritional quality, defensive traits, and levels of herbivory of $C$. thoermeri plants. Additionally, we included the use of a commercial fertiliser as an extra treatment to test whether the enhanced availability of soil nutrients is the mechanism behind the impacts of refuse dumps on the measured traits. Using leaves from those plants, we conducted a laboratory experiment aiming to examine their effect on caterpillar performance, measured as mass gain and feeding efficiency. We expected contrasting results depending on whether the excess of resources overall increased the quality/quantity of leaves and/or modified their defensive traits. If plants growing in nutrient-rich substrates represent an enhanced resource (e.g. more leaf nitrogen content and/or abundance of leaves), we expected that caterpillars feeding on nutrient-enhanced plants would show a better performance compared with those feeding on plants growing on unmodified steppe soils. Conversely, if enhanced nutrients trigger the production of more or better defensive leaf traits, over and above nutritional value or even in addition to increasing plant biomass and tissue quality, we expected that caterpillars feeding on nutrient-enhanced plants would diminish their food intake and/or show a lower performance compared with those feeding on control plants.

\section{Materials and methods}

\section{Study system}

Acromyrmex lobicornis Emery (Formicidae, Hymenoptera) is the only leaf-cutting ant species inhabiting the northwest Patagonian steppe (Farji-Brener \& Ruggiero, 1994). As reported for several leaf-cutting ant species (Farji-Brener \& Werenkraut, 2015), A. lobicornis changes the physical and chemical properties of the soil around their nest mainly by the accumulation of refuse dumps (Farji-Brener \& Ghermandi, 2008; Farji-Brener et al., 2010). Acromyrmex lobicornis collect vegetal material from a wide variety of plants, which is used as a substrate for growing a symbiotic fungus comprising the food for the ant brood. The waste products from this activity are accumulated in flat piles on the soil surface near the nest entrances. This organic waste generates nutrient-rich patches around the nest, usually colonised by exotic plant species that grow better and produce more seeds compared with the typical nutrient-poor soils of the arid steppes (Farji-Brener \& Ghermandi, 2008; Farji-Brener \& Werenkraut, 2015).

The thistle C. thoermeri (Asteraceae) (nodding thistle) is an exotic species abundant in the study area and one of the most common species growing in the nutrient-rich refuse dumps of A. lobicornis (Farji-Brener \& Ghermandi, 2008). This species is considered to be a noxious weed in pastures (Popay \& Medd, 1995), although its presence in roadsides of the Patagonian steppes may facilitate the abundance of native fauna (Lescano \& Farji-Brener, 2011). It is a monocarpic biennial herb that grows in a flat rosette during its first year of life and then, in the second year, it bolts and produces one or more stems with distinct purple inflorescences. This fast-growing species is capable of increasing its biomass when grown in appropriate microsites (Shea et al., 2005; Farji-Brener \& Ghermandi, 2008) and has both physical and chemical anti-herbivore defences such as sharp spines located on the leaf border (Lee \& Hamrick, 1983) and some flavonoids and alkaloids that act as chemical defences against herbivores (Jordon-Thaden \& Louda, 2003).

Copitarsia gibberosa Pogue is a noctuid moth found in western Argentina and throughout central Chile (Pogue, 2014) whose larvae are polyphagous and feed externally on leaves, stems, and fruits of many host plants (including numerous crops). The genus Copitarsia (Lepidoptera: Noctuidae) includes 21 species distributed from México throughout South America (Angulo \& Olivares, 2003); these species feed on a large number of 
fresh commodities (including alfalfa, apple, artichoke, asparagus, beet, cabbage, corn, kiwi, onion, raspberry, strawberry, tobacco, and wheat); thus, they are considered actionable pests and a risk to agriculture (Gould \& Maldonado, 2006; Pogue, 2014). An adult female of Copitarsia spp. may produce between 570 and 1640 eggs, depending on the quality of the environment and the host plant (Rojas \& Cibrian-Tovar, 1994). Larvae complete five to six instars during development, reaching up to $4 \mathrm{~cm}$ in length (Lopez-Avila, 1996), with pupation occurring in the soil and adult moths being grey or brown (Gould et al., 2005).

\section{Experimental design}

To determine the direct impact of nutrient-rich substrate on plant performance and defence traits, as well as their indirect effects on a generalist herbivore, we transplanted 30 second-year rosettes of $C$. thoermeri naturally growing in non-nest soils into individual pots. Each plant was placed in one of three substrate treatments: non-nest soils (Control), soil from refuse dumps of A. lobicornis (+ ant waste) or fertilised non-nest soils $(+\mathrm{NPK})(n=10$ replicates per treatment). Initial rosette plants were approximately $20 \times 25 \mathrm{~cm}$ in diameter and there was no difference in the number of fully developed leaves (between five and 10) among plants in the three treatments $\left(F_{2,27}=0.88\right.$, $P=0.42)$. Refuse dump material was collected in the field from five selected nests of A. lobicornis, combined and then used to fill 10 plastic pots (volume 7 litres). Substrate for non-nest soils (i.e. nutrient-poor soils) was collected from five non-nest sites near nests and combined to fill 20 plastic pots (volume 7 litres). Half of these 20 pots with non-nest soil were controls (i.e. Control treatment) and the other half were supplemented with $5 \mathrm{~g}$ of fertiliser $15: 15: 15$ nitrogen : phosphorous : potassium each (i.e. + NPK treatment). The fertiliser was applied twice over the course of the experiment: $2.5 \mathrm{~g}$ at the beginning and $2.5 \mathrm{~g} 1$ week later. Quantitative analyses of the fertiliser used indicated that it has approximately $12 \%$ nitrogen and $6.4 \%$ phophorous; hence, the total amounts of nitrogen and phophorous added were 0.65 and $0.32 \mathrm{~g}$, respectively, per pot. Similar effects on plant traits and larval performance between refuse dump and fertilised treatments would support the hypothesis that the effect of refuse dumps is a result of the enhanced availability of soil nutrients (rather than other possible mechanisms). All plants were randomly placed in a $1.5 \times 5 \mathrm{~m}$ plot, inside an open common garden where they grew under natural daylight and temperature conditions and were watered as needed. In addition, the plants were checked daily and herbivores were eliminated when necessary.

\section{Plant traits and defences}

After 50 days, several leaf traits were measured to characterise leaf quality for herbivores. For each plant, we counted the total number of leaves and estimated the foliar area as the average leaf area from nine leaves (three basal, three middle, and three top). The leaf area from each leaf was calculated using the formula for the area of an ellipse (area $=\pi \times A \times B$, where
$A$ is the semi-major axis and $B$ is the semi-minor axis from each leave). Also, we measured additional plant performance traits (i.e. maximum height and number of inflorescences, see Fig. S1) to compare our data with previous field studies. Plant quality was measured as leaf nutritional value $(\mathrm{C}: \mathrm{N}$ ratio and water content) and leaf physical defences were evaluated as leaf toughness, number of spines, and mean spine length. For chemical analysis of vegetal tissue, a sample of two leaves from each plant was collected and dried at $60{ }^{\circ} \mathrm{C}$ for $48 \mathrm{~h}$ up to constant weight. Subsequently, each sample was crushed into a fine powder with a mortar and pestle, and approximately 2-3 mg of dry weight (DW) was destined for elemental analysis. Carbon and nitrogen concentrations in the tissues were measured with a suitable analyser (Flash EA 1112; Thermo Scientific, Waltham, Massachusetts). Also, the same samples were used to calculate the leaf water content as: (wet mass - dry mass)/wet mass $) \times 100$. To estimate leaf toughness, as specific leaf area (SLA), we collected a total of eight leaf disks (diameter $2 \mathrm{~cm}$ ) (cut with a cork borer) from four leaves (two basal and two middle leaves) from each plant and calculated SLA as $A / M$, where $A$ is the area of the disks and $M$ is their mass (Milla et al., 2008). A lower SLA indicates higher leaf toughness because SLA is inversely correlated with fiber content (Gras et al., 2005). In the same four leaves, we counted the total number of spines from the third or fourth leaf lobule and measured the longest spine with a digital caliper. Plant performance and quality were analysed using one-way analysis of variance (ANOVA) with substrate included as a fixed factor with three levels. A posteriori comparisons among treatments were carried out when appropriate, using Tukey's test. The dependent variable $\mathrm{C}: \mathrm{N}$ ratio was log-transformed to meet the assumptions of ANOVA, whereas the total number of inflorescences was compared among the three substrate treatments using Kruskal-Wallis tests followed by a post hoc Dunn's test because this response variable failed to meet the normality assumptions of ANOVA.

To evaluate overall susceptibility to herbivore damage among plants growing in the different soil substrates, at the end of the experiment, herbivorous insects were allowed free access to all plants. After 10 days, we estimated natural herbivory levels by visually assessing the missing area of nine random leaves per plant (three basal, three middle, and three top leaves from each plant). We calculated the percentage of area consumed for each individual plant as the average of the nine measured leaves, and then, we estimated the percentage of each plant's leaf area removed as the product of the percentage of leaf area consumed and the foliar area of each plant. We compared the amount of damage among the three substrate types using Kruskal-Wallis tests.

\section{Caterpillar performance and feeding efficiency}

To determine whether plants growing on the different substrates differentially affect the performance and feeding efficiency of a generalist caterpillar, we set up a laboratory experiment. We collected third-instar larvae of C. gibberosa, occurring naturally around our experimental set up, and reared them on naturally occurring $C$. thoermeri for $24 \mathrm{~h}$. The next day, 
60 larvae were transferred, individually, to small, sealed plastic containers $\left(200 \mathrm{~mm}^{2}\right)$, starved for approximately $6 \mathrm{~h}$ to clear the gut, and then assigned randomly to feed on one of the three diet treatments: $C$. thoermeri leaves from individuals growing on non-nest soils (Control), refuse dumps of A. lobicornis (+ ant waste) or fertilised soils (+ NPK). To supply caterpillars with a constant source of fresh leaves, we harvested three or four undamaged leaves from each one of the 10 plants growing on each substrate (i.e. two basal and two middle leaves, each plant was used to rear two independent larvae). Four nutritional indices were calculated over an interval of $24 \mathrm{~h}$ according to the standard gravimetric method (Waldbauer, 1968): consumption index (CI), approximate digestibility (AD), efficiency of conversion of ingested food (ECI), and efficiency of conversion of digested food (ECD). Five measurements were collected per replicate: initial and final food mass (fresh weight), initial and final larval mass (fresh weight), and final faecal mass (dry weight). For the final measurements, caterpillars were starved for an additional $4 \mathrm{~h}$ before larval fresh weight and faecal dry weight were measured. A separate subset of larvae and leaves from each treatment diet was dried and weighed to obtain dry weight conversion factors. Larval relative growth rate (RGR), or dry mass increase per unit dry mass per day, was calculated as $\left[\left(W_{\mathrm{f}}-W_{\mathrm{i}}\right) / W_{\mathrm{i}}\right] / t$ where $W_{\mathrm{f}}$ is final biomass, $W_{\mathrm{i}}$ is initial biomass and $t$ is the total number of days (i.e. one in this case). To avoid problems with the statistical analysis of ratios, all nutritional indices were analysed using two-way analysis of covariance (Raubenheimer \& Simpson, 1992). In all cases, except for $\mathrm{CI}$, the numerator of the formula used to calculate each nutritional index was the dependent variable, whereas the denominator was used as a covariate. In the case of CI, the covariate was initial larval mass. In turn, variation in RGR was tested by a one-way ANOVA followed by Duncan's post hoc test. In all cases, diet treatment was included as fixed factor. Dependent and covariate variables were square root transformed to meet the assumptions of ANOVA.

Finally, to determine whether caterpillars regulate the imbalance in $\mathrm{C}: \mathrm{N}$ ratios between their food source and their biomass (stoichiometric homeostasis, sensu Sterner \& Elser, 2002), we carried out the elemental analysis of their excretions. The dried frass obtained after the $24 \mathrm{~h}$ feeding experiment was used to measure carbon and nitrogen concentrations with a suitable analyser (Flash EA 1112; Thermo Scientific). A sub-sample of 10 larvae from each diet treatment was used, and 2-3 mg of faecal material was used for elemental analysis. Data were log transformed to meet the assumptions of ANOVA and analysed using one-way ANOVA, with diet treatment as a fixed factor with three levels, and a posteriori comparisons among treatments were carried out using Tukey's tests.

\section{Results}

\section{Plant traits and defences}

Nutrient-rich substrates (+ NPK and + ant waste) increased plant biomass, as well as leaf nutritional quality and physical defences (Fig. 1); also, the effect of fertiliser (+ NPK) and refuse dumps (+ ant waste) were statistical indistinguishable in all cases, except the $\mathrm{C}: \mathrm{N}$ ratio (Fig. 1d). Plants grown in pots with refuse dumps and fertiliser showed approximately 1.4 times more leaves $\left(F_{2,27}=11.07, P<0.0001\right)$ and a 1.6 -fold greater mean foliar area $\left(F_{2,27}=9.67, P<0.005\right)$ than plants grown on control soils (Fig. 1a,b). Similarly, nutrient-rich substrates increased the number of inflorescences by approximately four-fold compared with plants in control pots $\left(F_{2,24}=26.28\right.$, $P<0.0001)$, although no differences in total plant height were observed $\left(F_{2,27}=0.30, P=0.74\right)$ (Fig. S1).

Plants grown on nutrient-rich substrates had approximately $7 \%$ less water than control plants $\left(F_{2,27}=18.34, P<0.0001\right)$ (Fig. 1c); however, leaf nitrogen content was approximately four-fold lower on control plants (Fig. S2). This difference in leaf nitrogen content explains the reduction in $\mathrm{C}: \mathrm{N}$ ratios by $72 \%$ and $83 \%$ in refuse dump and fertilised pots, respectively $\left(F_{2,27}=112.29, P<0.0001\right)$ (Fig. $\left.1 \mathrm{~d}\right)$. Lastly, in terms of physical defences, plants growing on refuse dump and fertilised soils showed an approximately two-fold higher leaf toughness (i.e. approximately 50\% lower mean SLA) and had approximately 1.7 times more spines than plants grown in control soils (Fig. 1e,f). There was no difference in the length of the longest spine across substrate types (mean \pm SE: Control $3.9 \pm 0.9,+$ ant waste $4.1 \pm 0.22$, and + NPK $6.2 \pm 1.2$; $F_{2,27}=1.02, P=0.37$ ).

The accumulated natural leaf damage of $C$. thoermeri plants was approximately $30 \%$ and did not depend on the treatment in which plants grew $\left(H_{2,30}=0.73, P=0.69\right)$ (Fig. 2a), although there was a strong tendency for greater leaf area removed in plants from refuse dump and fertilised soils compared with those from control soils $\left(H_{2,30}=5.49 ; P=0.06\right)$ (Fig. 2b).

\section{Caterpillar performance and feeding efficiency}

Nutrient-rich substrates led to a $60 \%$ increase in larval RGR compared with larvae reared on leaves from control plants $\left(F_{2,46}=8.51, P<0.001\right)$ (Fig. 3a). This trend might be explained by some measurements of caterpillar feeding efficiency because two of these indices were affected by the diet treatments (Table 1). Specifically, although leaf material consumed (CI) and approximate digestibility (AD) did not vary significantly among treatments (Fig. $3 \mathrm{~b}$ and Table 1), the herbivore efficiency with respect to conversion of ingested and digested food (ECI and ECD) was approximately 50\% and 40-90\% higher, respectively, for larvae feeding on leaves of refuse dump and fertilised plants compared with those feeding on control plants (Fig. 3c,d).

Also, nutrient-rich substrates significantly altered caterpillar nutrient excretion. Specifically, the carbon content of the caterpillar excretions was slightly but significantly, higher on the control plants $\left(F_{2,27}=3.98, P<0.05\right)$; however, more importantly, the nitrogen content of caterpillar excretions reared on leaves from enriched soils was approximately three-fold higher compared with those reared on control plants $\left(F_{2,27}=23.84\right.$, $P<0.0001$ ) (Fig. 4b). Accordingly, nutrient-rich substrates significantly decreased the $\mathrm{C}: \mathrm{N}$ ratio of caterpillar excretions by $77 \%\left(F_{2,7}=60.13, P<0.0001\right)($ Fig. $4 \mathrm{c})$. 
(a)

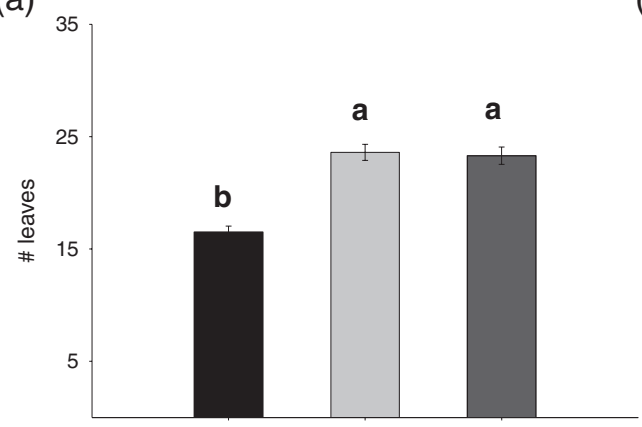

(c)

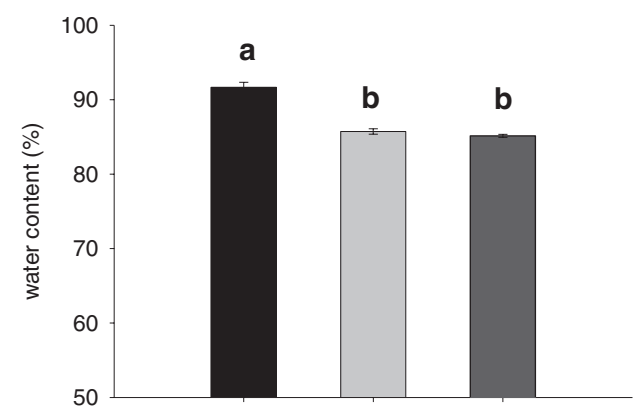

(e)

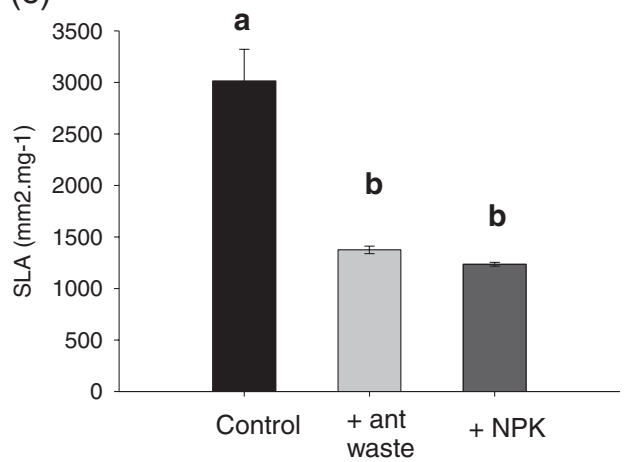

(b)

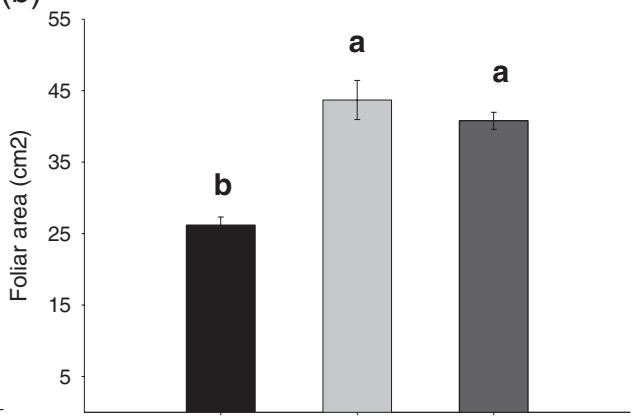

(d)

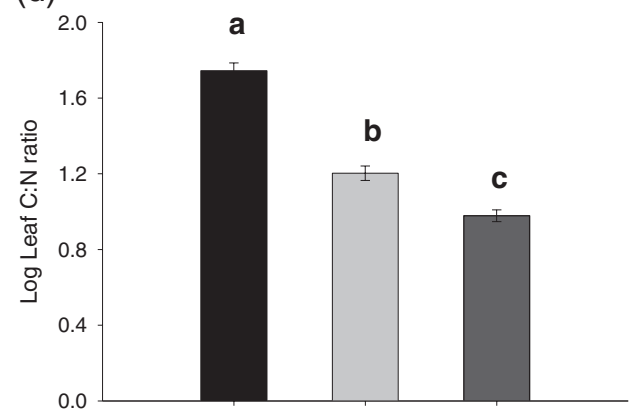

(f)

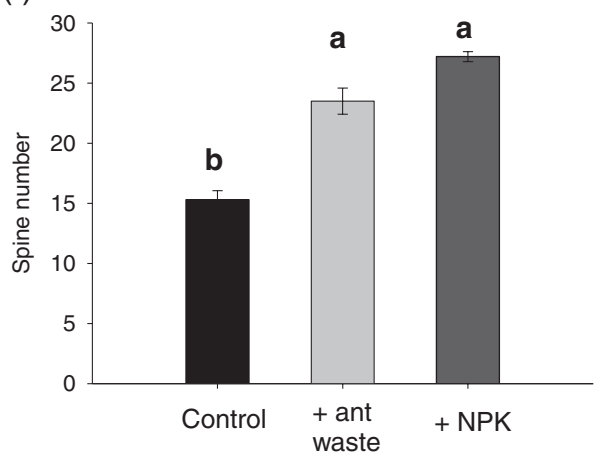

Fig. 1. Leaf traits (mean $\pm \mathrm{SE}$ ) of plants growing on non-nest soils (Control), refuse dumps of Acromyrmex lobicornis (+ ant waste), and fertilised soils (+ NPK). (a) total number of leaves, (b) foliar area, (c) water content, (d) log leaf carbon : nitrogen (C : N) ratio, (e) specific leaf area (SLA, with high values representing low leaf toughness), and (f) spine number. Different lower case letters indicate statistically significant differences among substrates (analysis of variance, $P<0.05$ ).

\section{Discussion}

The availability of soil nutrients affects the $\mathrm{C}: \mathrm{N}$ ratio of plants, which in turn determines the transfer of energy and nutrients through the trophic levels (Elser et al., 2003). Hence, the activity of soil-disturbing animals that increases the availability of resources for plants may trigger a bottom-up cascade, indirectly affecting the physiology and fitness of primary consumers. Although bottom-up cascades affecting primary consumers have been assessed for soil-disturbing animals such as sea birds (Kolb \& Hambäck, 2015) and mound-building termites (Dangerfield et al., 1998), few studies have reported the potential effects of bottom-up cascades triggered by leaf-cutting ants (Farji-Brener et al., 2009; Lescano et al., 2012). The present study demonstrated that the leaf-cutting ant A.lobicornis, through their nutrient-rich refuse dumps, enhanced the performance and nutritional quality of $C$. thoermeri, indirectly improving the feeding performance of caterpillars. In particular, we showed that $C$. thoermeri plants growing on ant-enriched soils had approximately $50 \%$ more and larger leaves and up to $80 \%$ lower $\mathrm{C}: \mathrm{N}$ ratio. Interestingly, plants on nutrient enhanced substrates were also better defended, with a $65 \%$ higher spine number and doubled leaf toughness compared with plants growing on common steppe soil. All measured plant traits, except leaf $\mathrm{C}: \mathrm{N}$ ratio, were similar between individuals growing on refuse dump and fertilised pots, supporting the idea that the enhanced availability of soil nutrients in ant refuse dumps is the source of the improved plant traits; further 
(a)

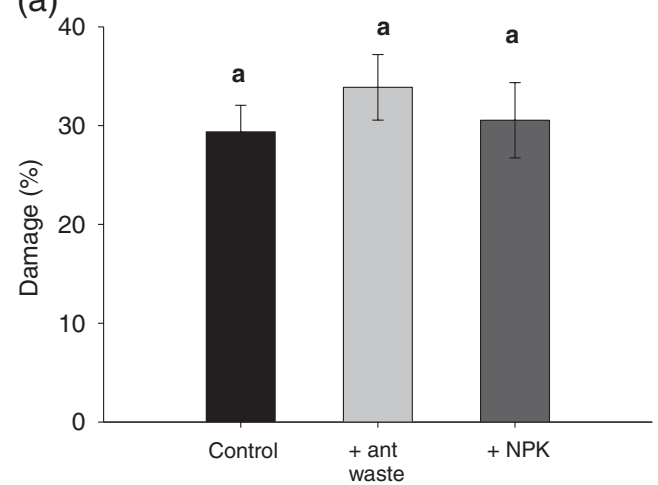

(b)

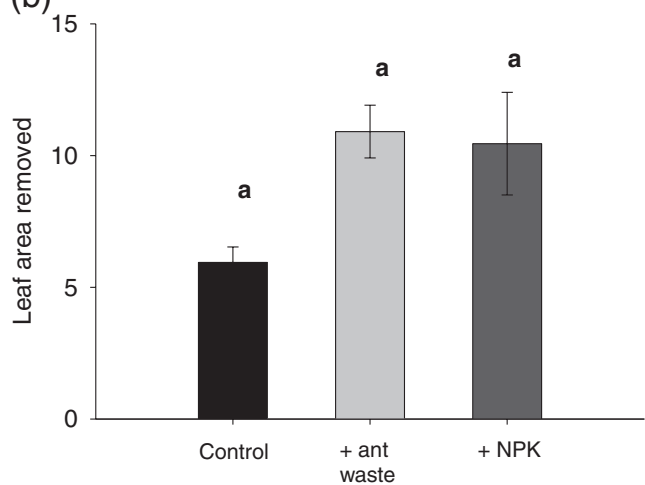

Fig. 2. Susceptibility to herbivore damage among plants growing on non-nest soils (Control), refuse dumps of Acromyrmex lobicornis (+ ant waste), and fertilised soils $(+\mathrm{NPK})$. (a) natural leaf damage and (b) area removed by herbivores. Different lower case letters indicate statistically significant differences among treatments $(P<0.05)$.

(a)

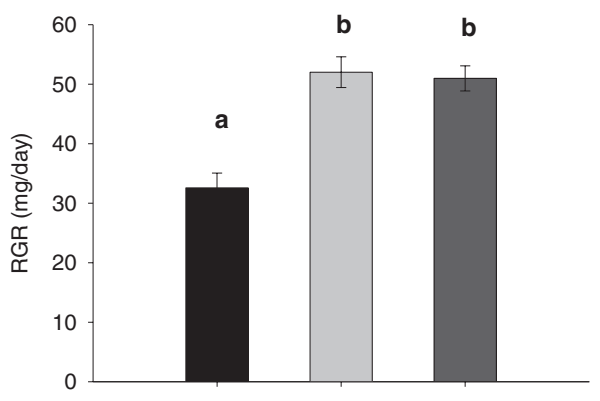

(c)

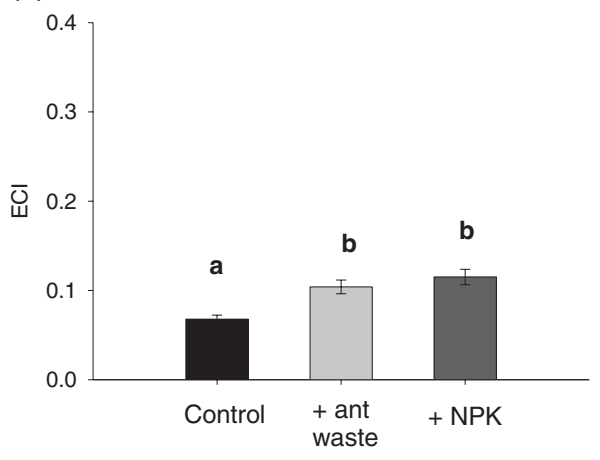

(b)

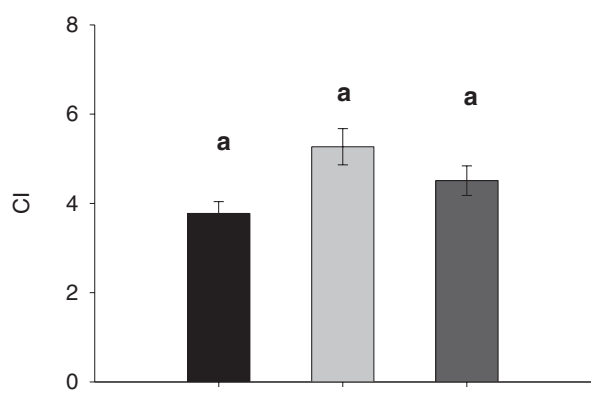

(d)

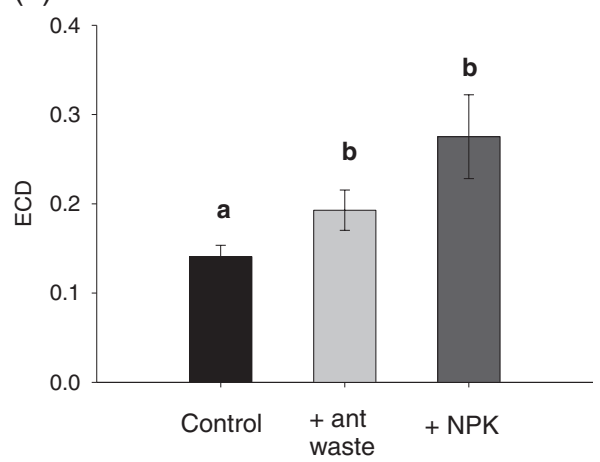

Fig. 3. Copitarsia gibberosa larval relative growth rate and nutritional indices (mean \pm SE) for individuals feeding for 24 h on three quality leaves [from plants growing on different substrates: non nest soils (Control), refuse dumps of Acromyrmex lobicornis (+ ant waste), and fertilised soils (+ NPK)]. (a) Relative growth rate (RGR), (b) consumption index (CI), (c) efficiency of conversion of ingested food (ECI), and (d) efficiency of conversion of digested food (ECD). Different lower case letters indicate statistically significant differences among substrates (analysis of variance for RGR and analysis of covariance for nutritional indices, $P<0.05$ ).

supporting the limiting nature of soil nutrients in the Patagonian steppes (Satti et al., 2003). Finally, ants and the refuse piles that they produce had indirect, positive effects on a generalist herbivore: $C$. gibberosa caterpillars reared on leaves from nutrient-rich substrates had $60 \%$ higher relative growth rate and enhanced digestive efficiencies of more than $40 \%$. In addition, the physiological cost of retaining nitrogen was reduced by approximately three-fold when larvae were reared on leaves from the nutrient-rich substrates compared with those reared on leaves from steppe soil. Thus, by increasing heterogeneity in plant traits, leaf-cutting ants can have a significant role on herbivore population dynamic and community structure.

The upward cascade effect of soil nutrient enrichment will be determined ultimately by how plants allocate the available resources. On the one hand, plants might allocate the increased resources to reproduction and/or growth, favouring 
Table 1. Results of the one-way analysis of covariance for caterpillar nutritional indices as a function of diet treatment.

\begin{tabular}{|c|c|c|c|c|c|c|c|c|c|c|c|c|}
\hline \multirow[b]{2}{*}{ Source } & \multicolumn{3}{|l|}{$\mathrm{CI}$} & \multicolumn{3}{|c|}{ ECI } & \multicolumn{3}{|l|}{$\mathrm{AD}$} & \multicolumn{3}{|c|}{ ECD } \\
\hline & d.f. & $F$ & $P$ & d.f. & $F$ & $P$ & d.f. & $F$ & $P$ & d.f. & $F$ & $P$ \\
\hline Covariate & 1 & 0.61 & 0.43 & 1 & 1.81 & 0.18 & 1 & 807.12 & $<0.0001$ & 1 & 0.15 & 0.69 \\
\hline Diet treatment & 2 & 1.41 & 0.25 & 2 & 8.59 & $<0.001$ & 2 & 2.11 & 0.13 & 2 & 8.71 & $<0.001$ \\
\hline Error & 45 & - & - & 45 & - & - & 45 & - & - & 45 & - & - \\
\hline
\end{tabular}

Significant effects are indicated in bold.

(a)

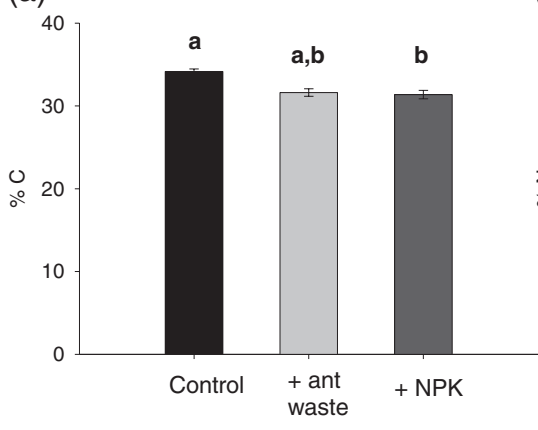

(b)

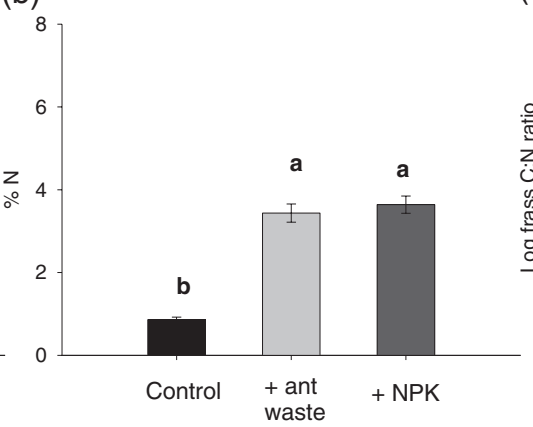

(c)

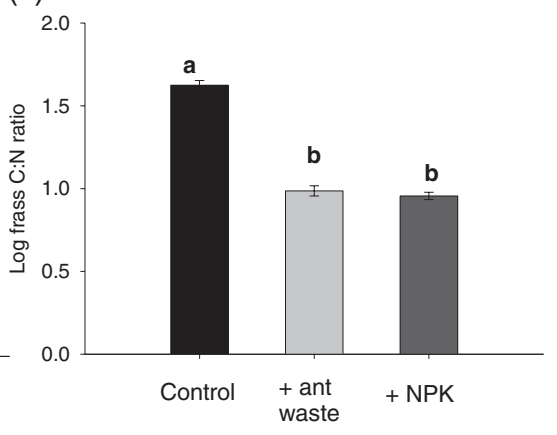

Fig. 4. Nutrient content of caterpillar excretion from individuals reared on three different diet treatments: Carduus thoermeri leaves from individuals growing on non-nest soils (Control), refuse dumps of Acromyrmex lobicornis (+ ant waste), or fertilised soils (+ NPK). (a) Percentage carbon content, (b) percentage nitrogen content, and (c) $\log$ frass $\mathrm{C}: \mathrm{N}$ ratio. Values are the mean $\pm \mathrm{SE}$ and different lower case letters indicate statistically significant differences among the diet treatments (analysis of variance, $P<0.05$ ).

herbivores by increasing access to less protected, more abundant resources (Forkner \& Hunter, 2000; Stiling \& Moon, 2005). On the other hand, plants may allocate the increased resources to enhance resistance traits, negatively affecting their herbivores (e.g. spines, tough tissue, toxic compounds) (Coley \& Barone, 1996; Cipollini \& Bergelson, 2001; Lou \& Baldwin, 2004). However, this dichotomous scenario is not necessarily the rule; instead, soil nutrient enrichment might improve, more or less, all plant functions (i.e. growth, reproduction, and defence), and so the consequences for herbivores will depend on the relative importance of each of them. This last possibility is supported by our results where $C$. thoermeri plants growing on more nutritious substrates showed more biomass, flowers, and physical defences compared with those growing on non-nest soils, as previously reported in field studies (Farji-Brener, 2007; Farji-Brener \& Ghermandi, 2008; Lescano et al., 2012), and they also had higher nutritional quality. Determining whether or not $C$. thoermeri thistles experience a trade-off between growth and defence functions is beyond the scope of the present study, and cannot be assessed completely because constitutive investment in chemical defences was not assessed, nor did we measure induced defences post damage.

Despite the large differences in thistle nutritional quality found in the present study, accumulated natural herbivory levels were similar across all three soil treatments (Fig. 2). One possibility, beyond differences in herbivore abundance among treatments, is that individual herbivores selecting less defended $C$. thoermeri plants from the control soil treatment increased their intake rates to compensate for poor diet quality, as seen in other systems
(Lee et al., 2003; Massey et al., 2006). Conversely, herbivores predicted to increase the consumption of $C$. thoermeri from nutrient-rich substrates in response to the increased tissue quality (Pérez-Harguindeguy et al., 2003; Cebrian \& Lartigue, 2004) might instead be limited by other plant traits, such as higher levels of indigestible fibre or a higher diversity or quantity of chemical defences (not measured in the present study). Although all of these traits, operating simultaneously, might have favoured intermediate levels of herbivory on different quality plants, natural herbivory measurements do not allow us to discriminate among the mechanisms underlying the feeding efficiency of herbivores and, thus, manipulative experiments become more informative.

According to stoichiometric theory, food consumed is a package of elements that may or may not be in balance with a consumer's elemental requirements. This imbalance is often greater at the base of food webs where the nutritional quality of plants usually differs from the nutritional demands of herbivores (Elser et al., 2000; Sterner \& Elser, 2002; Hillebrand et al., 2009). Consequently, herbivores have developed pre- and post-digestive mechanisms to maintain their nutrient balance, such as adjusting their ingestion rate or degree of food selectivity (Plath \& Boersma, 2001; Raubenheimer \& Simpson, 2003), assimilation (Sabat et al., 1999) or excretion (He \& Wang, 2008) processes. These mechanisms may increase nutritional gains, although often at the expense of higher energetic costs (Relyea \& Auld, 2004). Our laboratory experiments showed that, although the ingestion rate was not adjusted, assimilation and excretion processes varied in response to diet treatments. In particular, caterpillar reared with leaves from $C$. thoermeri 
growing in control steppe soil pots did not show an increase in consumption rates, as might be expected to compensate for the poor quality of the diet (Raubenheimer, 1992; Behmer et al., 2002). This lack of response could be explained by the fact that increasing food consumption implies adjusting to excess carbon, which is energetically expensive (Sterner \& Elser, 2002). However, despite showing equal consumption rate among treatments, nutrient-rich substrates had an indirect positive impact on caterpillar growth rate, probably as a result of higher digestive performance (enhanced ECI and ECD) when reared on rich-soil plants, as documented in other systems (Giertych et al., 2005). Although the influence of leaf quality on caterpillar feeding efficiency could change with their developmental stage (Lebigre et al., 2018; Quintero \& Bowers, 2018), the results of the present study suggest that the enhanced nutritional quality of thistles growing on a better substrate would compensate for the expected diminished efficiency of conversion of ingested and digested food (ECI, ECD) as a result of enhanced physical defences (Hochuli, 1996; Clissold et al., 2009), at least for the larval stage investigated in the present study. Similarly, although not measured, it could be that thistles growing on nutrient-rich soils had higher levels of chemical defences; yet, the similar and higher digestion efficiencies in refuse dump and fertilised plants suggest that such changes did not take place or that any changes in chemical defence were insufficient to affect digestion efficiencies. By contrast, although defences might have played a small role in affecting $C$. gibberosa caterpillar performance, a higher nutrient quality appears to be the key trait favouring caterpillar growth. Hence, as the nitrogen content of their food increases, herbivores become more efficient in converting plant material into body tissue (Schoonhoven et al., 1998); probably as a result of the lower cost of retaining nitrogen when the diet begins to be richer in this element.

Nitrogen is considered one of the most limiting macronutrients for herbivorous insects and consequently, maintaining their internal homeostasis under diets with lower nitrogen imposes costs that can translate into reduced fitness (Elser et al., 2000; Sterner \& Elser, 2002). Herbivores can regulate their elemental composition by increasing the excretion of excessive elements and/or the retention of scarce elements (Sterner \& Elser, 2002). Our laboratory experiment showed that nitrogen content of caterpillar excretions increased as the $\mathrm{C}: \mathrm{N}$ ratio of their food decreased (i.e. larvae reared on refuse dump and fertilised leaves excrete three times more nitrogen compared with those reared on control plants), suggesting that C. gibberosa is able to adjust their excretion to regulate the relative acquisition of nutrients, according to the excretion hypothesis (Sterner \& Elser, 2002). This suggests that enhanced-soil nutrients bring leaf nutritional quality closer to larval requirements, relaxing the need to retain nitrogen. Although the present study examined the performance of a single larval stage under laboratory conditions, our results are in accordance with the inverse relationship between nitrogen excreted and $\mathrm{C}: \mathrm{N}$ of the food reported for other herbivores (Balseiro \& Albariño, 2006) and the increased retention efficiency demonstrated to mitigate phosphorous deficiencies (DeMott et al., 1998). Thus, the higher energetic costs of retaining nitrogen when it is scarce (Sterner \& Elser, 2002) may be diminished when caterpillars feed on plants from nutrient-rich substrates, further explaining their increased performance. This hypothesis is supported by both the higher nitrogen content of excretions and the $60 \%$ higher RGR of $C$. gibberosa larvae reared on refuse dump and fertilised plants compared with those reared on control leaves.

In summary, we have shown that nutrient-rich refuse dumps of the leafcutter ants A. lobicornis have a positive effect on the nutritional quality of $C$. thoermeri plants, which indirectly benefits a generalist caterpillar that feeds on those plants. In particular, we show that the increase in soil nutrient availability diminished the stoichiometric constraints at the base of the food chain by bringing the $\mathrm{C}: \mathrm{N}$ ratio of thistles closer to one that satisfies herbivore requirements, with positive consequences for larval development and growth rates. Although the outcomes of this increased performance were not measured directly in the present study, it is well established that there are strong positive associations between larval size and adult fecundity and fitness (Honěk, 1993). Moreover, given that specialist herbivores may be less sensitive to host plant defences or could make more efficient use of host nutrients (Coley et al., 2006), we might be underestimating the actual role of nutrient-rich refuse dumps on herbivore community dynamics. Therefore, the present study highlights the important role played by the activity of soil-disturbing animals, such as leaf-cutting ants, in indirectly mediating plant-herbivore interactions.

\section{Acknowledgements}

We thank M. Deane Bowers and two anonymous reviewers for their valuable comments and suggestions that improved the quality of the manuscript. We are especially grateful to Dr Cecilia Laspoumaderes for methodological support with elemental analysis, Lic. Patricia Suarez for greenhouse assistance, and Pablo Alvear and Ariel Mayoral for field assistance. This research was partially funded by the argentinean Agencia Nacional de Promoción Científica y Tecnológica, PICT 2015-0578 to MNL and PICT 2014-1233 to CQ.

\section{Supporting Information}

Additional supporting information may be found online in the Supporting Information section at the end of the article.

Figure S1. Mean \pm SE number of general plant traits measured in individuals assigned to different substrate types: non-nest soils $(\mathrm{NNS}=\mathrm{Control})$, refuse dumps of Acromyrmex lobicornis $(\mathrm{RD}=+$ ant waste $)$, and fertilised soils $(\mathrm{FER}=+\mathrm{NPK})$. (a) Maximum height. (b) Inflorescences number. Different lowercase letters indicate statistically significant differences among substrates (one-way analysis of variance, $P<0.05$ ).

Figure S2. Mean \pm SE of nutrient content from leaves of Carduus thoermeri growing on three different substrates: non-nest soils $(\mathrm{NNS}=\mathrm{Control})$, refuse dumps of Acromyrmex lobicornis $(\mathrm{RD}=+$ ant waste), and fertilised soils $(\mathrm{FER}=+\mathrm{NPK})$. (a) Percentage carbon content. (b) Percentage nitrogen content. Results of the one-way analysis of variance design $\left(F_{2,27}=0.74\right.$, $P=0.78$ and $F_{2,27}=53.61, P<0.001$, respectively $)$. Different 
lowercase letters indicate statistically significant differences among the diet treatments.

\section{References}

Agrawal, A.A. (2011) Current trends in the evolutionary ecology of plant defence. Functional Ecology, 25, 420-432.

Angulo, A.O. \& Olivares, T.S. (2003) Actualización taxonómica de las especies de Copitarsia Hampson 1906, (Lepidoptera: Noctuidae: Cucullinae). Gayana, 67, 33-38.

Balseiro, E. \& Albariño, R. (2006) C-N mismatch in the leaf litter-shredder relationship of an Andean Patagonian stream detritivore. Journal of the North American Benthological Society, 25, 607-615.

Behmer, S.T., Simpson, S.J. \& Raubenheimer, D. (2002) Herbivore foraging in chemically heterogeneous environments: nutrients and secondary metabolites. Ecology, 83, 2489-2501.

Bryant, J.P., Chapin, F.S. \& Klein, D.R. (1983) Carbon/nutrient balance of boreal plants in relation to vertebrate herbivory. Oikos, 40, 357-368.

Cebrian, J. \& Lartigue, J. (2004) Patterns of herbivory and decomposition in aquatic and terrestrial ecosystems. Ecological Monographs, 74, 237-259.

Cipollini, D.F. \& Bergelson, J. (2001) Plant density and nutrient availability constrain constitutive and wound-induced expression of trypsin inhibitors in Brassica napus. Journal of Chemical Ecology, 27, 593-610.

Clissold, F.J., Sanson, G.D., Read, J. \& Simpson, S.J. (2009) Gross vs. net income: how plant toughness affects performance of an insect herbivore. Ecology, 90, 3393-3405.

Coley, P.D. \& Barone, J.A. (1996) Herbivory and plant defenses in tropical forests. Annual Review of Ecology and Systematics, 27, 305-335.

Coley, P.D., Bateman, M.L. \& Kursar, T.A. (2006) The effects of plant quality on caterpillar growth and defense against natural enemies. Oikos, 115, 219-228.

Dangerfield, J.M., McCarthy, T.S. \& Ellery, W.N. (1998) The mound-building termite Macrotermes michaelseni as an ecosystem engineer. Journal of Tropical Ecology, 14, 507-520.

DeMott, W.R., Gulati, R.D. \& Siewertsen, K. (1998) Effects of phosphorus-deficient diets on the carbon and phosphorus balance of Daphnia magna. Limnology and Oceanography, 43, 1147-1161.

Dyer, L.A., Letourneau, D.K., Dodson, C.D., Tobler, M.A., Stireman, J.O. \& Hsu, A. (2004) Ecological causes and consequences of variation in defensive chemistry of a Neotropical shrub. Ecology, 85, 2795-2803.

Eldridge, D.J. \& James, A.I. (2009) Soil disturbance by native animals plays a critical role in maintaining healthy Australian landscapes. Ecological Management \& Restoration, 10, S27-S34.

Elser, J.J., Fagan, W.F., Denno, R.F. \& Dobberfuhl, D.R. (2000) Nutritional constraints in terrestrial and freshwater food webs. Nature, 408, 578-580.

Elser, J.J., Acharya, K., Kyle, M., Cotner, J., Makino, W., Markow, T. et al. (2003) Growth rate-stoichiometry couplings in diverse biota. Ecology Letters, 6, 936-943.

Farji-Brener, A.G. (2007) How plants may benefit from their consumers: leaf-cutting ants indirectly improve anti-herbivore defenses in Carduus nutans L. Plant Ecology, 193, 31-38.

Farji-Brener, A.G. \& Ghermandi, L. (2008) Leaf-cutting ant nests near roads increase fitness of exotic plant species in natural protected areas. Proceedings of the Royal Society of London Series B: Biological Sciences, 275, 1431-1440.
Farji-Brener, A.G. \& Ruggiero, A. (1994) Leaf-cutting ants (Atta and Acromyrmex) inhabiting Argentina: patterns in species richness and geographical range sizes. Journal of Biogeography, 21, 391-399.

Farji-Brener, A.G. \& Werenkraut, V. (2015) A meta-analysis of leaf-cutting ant nest effects on soil fertility and plant performance. Ecological Entomology, 40, 150-158.

Farji-Brener, A.G. \& Werenkraut, V. (2017) The effects of ant nests on soil fertility and plant performance: a meta-analysis. Journal of Animal Ecology, 86, 866-877.

Farji-Brener, A.G., Gianoli, E. \& Molina-Montenegro, M.A. (2009) Small-scale disturbances spread along trophic chains: leaf-cutting ant nests, plants, aphids, and tending ants. Ecological Research, 24, 139-145.

Farji-Brener, A.G., Lescano, N. \& Ghermandi, L. (2010) Ecological engineering by a native leaf-cutting ant increases the performance of exotic plant species. Oecologia, 163, 163-169.

Forkner, R.E. \& Hunter, M.D. (2000) What goes up must come down? Nutrient addition and predation pressure on oak herbivores. Ecology, 81, 1588-1600.

Giertych, M.J., Bąkowski, M., Karolewski, P., Zytkowiak, R. \& Grzebyta, J. (2005) Influence of mineral fertilization on food quality of oak leaves and utilization efficiency of food components by the gypsy moth. Entomologia Experimentalis et Applicata, 117, 59-56.

Gould, J.R. \& Maldonado, M.H. (2006) Copitarsia decolora (Lepidoptera: Noctuidae) larvae escaping from discarded asparagus: data in support of a pathway risk analysis. Journal of Economic Entomology, 99, 1605-1609.

Gould, J.R., Venette, R. \& Winograd, D. (2005) Effect of temperature on development and population parameters of Copitarsia decolora (Lepidoptera: Noctuidae). Environmental Entomology, 34, 548-556.

Gras, E.K., Read, J., Mach, C.T., Sanson, G.D. \& Clissold, F.J. (2005) Herbivore damage, resource richness and putative defences in juvenile versus adult Eucalyptus leaves. Austral Journal of Botany, 53, 33-44.

Hartley, A., Barger, N., Belnap, J. \& Okin, G.S. (2007) Dryland ecosystems. Nutrient Cycling in Terrestrial Ecosystems (ed. by P. Marschner and Z. Rengel), pp. 271-307. Springer, Berlin, Germany.

He, X. \& Wang, W.X. (2008) Stoichiometric regulation of carbon and phosphorus in P-deficient Daphnia magna. Limnology and Oceanography, 53, 244-254.

Hillebrand, H., Borer, E.T., Bracken, M.E., Cardinale, B.J., Cebrian, J., Cleland, E.E. et al. (2009) Herbivore metabolism and stoichiometry each constrain herbivory at different organizational scales across ecosystems. Ecology Letters, 12, 516-527.

Hochuli, D.F. (1996) The ecology of plant/insect interactions: implications of digestive strategy for feeding by phytophagous insects. Oikos, 75, 133-141.

Honěk, A. (1993) Intraspecific variation in body size and fecundity in insects: a general relationship. Oikos, 66, 483-492.

Hoque, S. \& Avila-Sakar, G. (2014) Trade-offs and ontogenetic changes in resistance and tolerance to insect herbivory in Arabidopsis. International Journal of Plant Sciences, 176, 150-158.

Huberty, A.F. \& Denno, R.F. (2006) Consequences of nitrogen and phosphorus limitation for the performance of two planthoppers with divergent life-history strategies. Oecologia, 149, 444-455.

Hunter, M.D. (2016) The Phytochemical Landscape: Linking Trophic Interactions and Nutrient Dynamics. Princeton University Press, Princeton, New Jersey.

Jordon-Thaden, I.E. \& Louda, S.M. (2003) Chemistry of Cirsium and Carduus: a role in ecological risk assessment for biological control of weeds? Biochemical Systematics and Ecology, 31, 1353-1396.

Kerslake, J.E., Woodin, S.J., \& Hartley, S.E. (1998) Effects of carbon dioxide and nitrogen enrichment on a plant-insect interaction: the 
quality of Calluna vulgaris as a host for Operophtrea brumata. New Phytol 140: 43-53

Kolb, G. \& Hambäck, P.A. (2015) Dynamic responses in a plant-insect system to fertilization by cormorant feces. Insects, $\mathbf{6}, 419-431$.

Koricheva, J. (2002) Meta-analysis of sources of variation in fitness costs of plant anti-herbivore defenses. Ecology, 83, 176-190.

Lebigre, C., Vanderbeken, C., Turlure, C. \& Schtickzelle, N. (2018) Host plant nitrogen enrichment has both positive and negative effects on the larval growth of a specialist butterfly. Ecological Entomology, $\mathbf{4 3}$, 494-505.

Lee, J.M. \& Hamrick, J.L. (1983) Demography of two natural populations of musk thistle (Carduus nutans). The Journal of Ecology, 71, 923-936.

Lee, K.P., Raubenheimer, D., Behmer, S.T. \& Simpson, S.J. (2003) A correlation between macronutrient balancing and insect host-plant range: evidence from the specialist caterpillar Spodoptera exempta (Walker). Journal of Insect Physiology, 49, 1161-1171.

Lescano, M.N. \& Farji-Brener, A.G. (2011) Exotic thistles increase native ant abundance through the maintenance of enhanced aphid populations. Ecological Research, 26, 827-834.

Lescano, M.N., Farji-Brener, A.G., Gianoli, E. \& Carlo, T.A. (2012) Bottom-up effects may not reach the top: the influence of ant-aphid interactions on the spread of soil disturbances through trophic chains. Proceedings of the Royal Society of London Series B: Biological Sciences, 279, 3779-3787.

Lopez-Avila, A. (1996) Insectos plagas del cultivo de la papa en Colombia y su manejo. Comunicaciones y Asociados Ltda, Santa fe de Bogotá, Colombia.

Lou, Y. \& Baldwin, I.T. (2004) Nitrogen supply influences herbivore-induced direct and indirect defenses and transcriptional responses in Nicotiana attenuata. Plant Physiology, 135, 496-506.

Massey, F.P., Ennos, A.R. \& Hartley, S.E. (2006) Silica in grasses as a defense against insect herbivores: contrasting effects on folivores and a phloem feeder. Journal of Animal Ecology, 75, 595-603.

Milla, R., Reich, P.B., Niinemets, U. \& Castro-Diez, P. (2008) Environmental and developmental controls on specific leaf area are little modified by leaf allometry. Functional Ecology, 22, 565-576.

Mun, H.T.A.E. \& Whitford, W.G. (1990) Factors affecting annual plants assemblages on banner-tailed kangaroo rat mounds. Journal of Arid Environment, 18, 165-173.

Neilson, E.H., Goodger, J.Q.D., Woodrow, I.E. \& Lindberg Møller, B. (2013) Plant chemical defense: at what cost? Trends in Plant Science, 18, 250-258.

Noy-Meir, I. (1973) Desert ecosystems: environment and producers. Annual Review of Ecology and Systematics, 4, 25-51.

Orians, C.M., Hochwender, C.G., Fritz, R.S. \& Snall, T. (2010) Growth and chemical defense in willow seedlings: trade-offs are transient. Oecologia, 163, 283-290.

Pérez-Harguindeguy, N., Díaz, S., Vendramini, F., Cornelissen, J.H., Gurvich, D.E. \& Cabido, M. (2003) Leaf traits and herbivore selection in the field and in cafeteria experiments. Austral Ecology, 28, 642-650.

Perkinns, M.C., Woods, H.A., Harrison, J.F. \& Elser, J.J. (2004) Dietary phosphorus affects the growth of larval Manduca sexta. Archives of Insect Biochemistry and Physiology, 55, 153-168.
Plath, K. \& Boersma, M. (2001) Mineral limitation of zooplankton: stoichiometric constraints and optimal foraging. Ecology, 82, $1260-1269$.

Pogue, M.G. (2014) A Review of the Copitarsia decolora (Guenée) (Lepidoptera: Noctuidae) species complex with the description of a new species from Chile and Argentina. Neotropical Entomology, 43, $143-153$

Popay, A.I. \& Medd, R.W. (1995) Carduus nutans L. ssp. nutans. The Biology of Australian Weeds, 1, 29-49.

Quintero, C. \& Bowers, M.D. (2018) Plant and herbivore ontogeny interact to shape the preference, performance and chemical defense of a specialist herbivore. Oecologia, 187, 401-412.

Raubenheimer, D. (1992) Tannic acid, protein, and digestible carbohydrate: dietary imbalance and nutritional compensation in locusts. Ecology, 73, 1012-1027.

Raubenheimer, D. \& Simpson, S.L. (1992) Analysis of covariance: an alternative to nutritional indices. Entomologia Experimentalis et Applicata, 62, 221-231.

Raubenheimer, D. \& Simpson, S.J. (2003) Nutrient balancing in grasshoppers: behavioural and physiological correlates of dietary breadth. Journal of Experimental Biology, 206, 1669-1681.

Relyea, R.A. \& Auld, J.R. (2004) Having the guts to compete: how intestinal plasticity explains costs of inducible defences. Ecology Letters, 7, 869-875.

Rojas, J.C. \& Cibrian-Tovar, J. (1994) Reproductive behavior of Copitarsia consueta (Walker) (Lepidoptera: Noctuidae): mating frequency, effect of age on mating, and influence of delayed mating on fecundity and egg fertility. Pan-Pacific Entomologist, 70, 273-286.

Sabat, P., Lagos, J.A. \& Bozinovic, F. (1999) Test of the adaptive modulation hypothesis in rodents: dietary flexibility and enzyme plasticity. Comparative Biochemistry and Physiology Part A: Molecular \& Integrative Physiology, 123, 83-87.

Sampedro, L., Moreira, X. \& Zas, R. (2011) Costs of constitutive and herbivore-induced chemical defences in pine trees emerge only under low nutrient availability. Journal of Ecology, 99, 818-827.

Satti, P., Mazzarino, M.J., Gobbi, M., Funes, F., Roselli, L. \& Fernandez, H. (2003) Soil N dynamics in relation to leaf litter quality and soil fertility in north-western Patagonian forests. Journal of Ecology, 91, $173-181$.

Schoonhoven, L.M., Jermy, T. \& Van Loon, J.J.A. (1998) Plants as insect food: not the ideal. Insect-Plant Biology (ed. by L. M. Schoonhoven, T. Jermy and J. J. A. Van Loon), pp. 83-120. Chapman and Hall, New York, New York.

Shea, K., Kelly, D., Sheppard, A.W. \& Woodburn, T.L. (2005) Context-dependent biological control of an invasive thistle. Ecology, 86, 3174-3181.

Sterner, R.W. \& Elser, J.J. (2002) Ecological Stoichiometry: The Biology of Elements from Molecules to the Biosphere. Princeton University Press, Woodstock, U.K.

Stiling, P. \& Moon, D.C. (2005) Quality or quantity: the direct and indirect effects of host plants on herbivores and their natural enemies. Oecologia, 142, 413-420.

Waldbauer, G.P. (1968) The consumption and utilization of food by insects. Advances in Insect Physiology, 5, 229-288.

Accepted 26 June 2018

Associate Editor: Toomas Tammaru 